\title{
Article \\ Early Intervention against Desert Locusts: Current Proactive Approach and the Prospect of Sustainable Outbreak Prevention
}

\author{
Allan T. Showler ${ }^{1, *}$, Mohammed Abdallahi Ould Babah Ebbe ${ }^{2}$, Michel Lecoq $^{3}{ }^{(1)}$ and Koutaro O. Maeno ${ }^{4}$ \\ 1 USDA-ARS Knipling-Bushland U.S. Livestock Insects Research Laboratory, 2700 Fredericksburg Road, \\ Kerrville, TX 78028, USA \\ 2 Sahel Institute, Bamako, BP 1530, Mali; mohamedabdellahi.ebbe@cilss.int \\ 3 CIRAD, UMR CBGP, F-34398 Montpellier, France; mlecoq34@gmail.com \\ 4 Japan International Research Center for Agricultural Sciences, Livestock and Environment Division, \\ Ohwashi 1-1, Tsukuba 305-8686, Japan; kmaeno@affrc.go.jp \\ * Correspondence: Allan.Showler@usda.gov
}

Citation: Showler, A.T.; Ould Babah Ebbe, M.A.; Lecoq, M.; Maeno, K.O. Early Intervention against Desert Locusts: Current Proactive Approach and the Prospect of Sustainable Outbreak Prevention. Agronomy 2021, 11, 312. https://doi.org/10.3390/ agronomy 11020312

Academic Editor: Imre J. Holb

Received: 8 January 2021

Accepted: 7 February 2021

Published: 10 February 2021

Publisher's Note: MDPI stays neutral with regard to jurisdictional claims in published maps and institutional affiliations.

Copyright: (c) 2021 by the authors. Licensee MDPI, Basel, Switzerland. This article is an open access article distributed under the terms and conditions of the Creative Commons Attribution (CC BY) license (https:// creativecommons.org/licenses/by/ $4.0 /)$.

\begin{abstract}
The desert locust, Schistocerca gregaria (Forskål) (Orthoptera: Acrididae), a major Old World pest, is associated with agricultural losses and undesirable societal effects. There are three broad approaches to its control: reaction, proaction, and outbreak prevention. Reaction protects crops from swarms but it is costly and disruptive. Proaction involves early intervention during outbreaks to avert further development to plague status; it is in current use because it is effective, relatively inexpensive, and it is the best available option for now. Outbreak prevention, largely unavailable since the 1970s, at least on a regional scale, will require highly sensitive surveillance to detect the onset of gregarization. Sufficiently early intervention can, hypothetically, extend desert locust recession indefinitely. While research on desert locust biology and behavior is, almost, no longer an urgent requirement to improve the efficacy of control, new priorities have arisen for developing outbreak prevention capability (and for enhancing proaction). Salient needs presently include long residual tactics for prophylactic (preventive) control in breeding areas, intervention thresholds, and improved, sustainable coordination among stakeholders at national, regional, and international levels. The most recent desert locust episode of 2020 provides an illustrative example of how prevention might have averted the entire upsurge, and how proaction in some countries contained the spread of swarms. The initial outbreak in Saudi Arabia escaped control due to unpreparedness, and impacts of armed conflict in Somalia and Yemen, which weakened surveillance and control, further contributed to the invasion of $\geq 22$ countries, and the spraying of $\approx 4.9$ million ha, by the end of 2020 .
\end{abstract}

Keywords: control; plague; proaction; Schistocerca gregaria; surveillance; threshold; upsurge

\section{Introduction}

Basic scientific principles for controlling the desert locust, Schistocerca gregaria (Forskål) (Orthoptera: Acrididae), were established during the first half of the 20th century. Following the elucidation of phase theory (whereby the pest can change between solitary and gregarious morphologies and behaviors) by Uvarov [1] and the location of major desert locust breeding areas in which outbreaks tend to originate, the Fifth International Locust Conference, held in Brussels, 1938, promulgated the need for international coordination as well as the possibility of developing a preventative strategy against swarm formation [2]. Since that time, scientific and technical advances have been substantial, greatly improving approaches to surveillance and control [3,4]. Desert locust control strategy, however, has remained a topic of considerable debate. In recent years there has been extensive discussion of early intervention strategies [3-16]. The desert locust is a biologically and behaviorally complex insect $[11,17]$ that, when gregarious and uncontrolled, is often fraught with adverse economic, environmental, and social consequences $[3,8,10,11,16,18-21]$. 


\section{Prevention Is Relative}

Constructive discussion of desert locust control is often confounded by different perspectives on common terminology [11]. Regarding "prevention", confusion arises from disharmonious views on what we intend to prevent. Do we permit the occurrence of upsurges before intervening to prevent plague development? Or is the ultimate goal to prevent outbreaks, thereby maintaining recession status indefinitely [9]? To prevent is to avert an event or condition, precluding its occurrence. Outbreak prevention is gregarization management; it entails intervention prior to, or during, phase transformation from solitary to gregarious $[9,10,12,21]$. Intervention during outbreaks, on the other hand, is aptly described as "proaction", aimed at halting an outbreak's expansion toward plague status [9]. There are, broadly, three desert locust control approaches: reaction, proaction, and outbreak prevention $[4,8-11]$.

\subsection{Reaction}

The reactive approach involves intervention after economically and socially threatening desert locust upsurges and plagues are underway [11], a result of unpreparedness to take action earlier. Reaction primarily focuses on defensively protecting croplands from destruction instead of offensively intervening in the main breeding areas (commonly in remote regions) $[11,17,19]$. Major upsurges and plagues, unfortunately, are associated with serious economic losses and social upheaval $[11,20]$.

Some observers from countries unafflicted by desert locusts have espoused allowing plagues to build and run their course without intervention; they propose that farmers who incur losses will later receive compensation through insurance policies [22], and that reactive campaigns are, on average, less expensive $[13,14]$ than early intervention. Both views are cavalier, after Europe and United States took strong measures to decimate their own locust populations (e.g., Rocky Mountain locusts, Melanoplus spretus [Walsh]) [11,23], and because insurance is impractical where it is largely an unfamiliar concept and where subsistence agriculture predominates. Calculating costs associated with gregarious desert locust episodes is challenging $[8,9,11,19,24]$ because it involves the monetary value of crops; the social implications of subsistence agriculture; negative impacts on pasturage, rangeland, and livestock; food aid; assistance for displaced people; and long-term impact on populations and education outcomes [20,21,25]. Economic assessments are available [17,18,26-31], but they are not necessarily complete. Agricultural losses were suggested as being insufficient to warrant investment in control [22], but that was founded on the cash value of selected crop systems without considering the array of other factors. The 2003-2005 upsurge, for example, was conservatively assessed to have inflicted an average crop loss of $\approx 30 \%$, but that estimate failed to incorporate losses incurred by small Sahelian farms and to consider areas suffering from particularly severe food shortages $[11,20,21]$. The 2003-2005 upsurge further resulted in displacement of farmers and pastoralists to urban areas; conflicts between farmers, nomads, and pastoralists over limited resources; declines in market commodities that offset agricultural product prices; and food aid from international agencies (donors), and multiple cascades of indirect socio-economic impacts [20,29-34]. Belayneh [20] conservatively estimated crop losses of 10-20\%, while loss of anticipated cereal harvest reached $80 \%, 90 \%$, and 100\% during 2004 in areas of Burkina Faso, Mali, and Mauritania, respectively [21]. Legume crop reductions were as much as $90 \%$ in the same three countries; further, $\approx 30 \%$ of pasture vegetation was destroyed in Mali and Burkina Faso, and fodder production was reduced by up to $80 \%$ in Mauritania, resulting in a total of $\approx 8.4$ million affected sahelian farmers and pastoralists [21].

While it can be argued that reaction is, technically, preventive by aiming to avert crop losses under some circumstances, reaction is not regarded as being a preventive strategy. Reaction is instead a default response when desert locust activity becomes overwhelming and threatens agricultural production [9-12]. Examples of reactive control include the 1986-1989, 1992-1995, and the 2003-2005 campaigns $[5,8,10,11,20]$. Each of those campaigns was expensive in terms of international aid (US\$ millions $\approx 300, \approx 19$, and 
$\approx 35$, respectively) and involved 18-23 desert locust afflicted countries in Africa and Asia (Table 1) $[5,8,10,11,20]$.

Table 1. Desert locust episode and control effort statistics 1986-2016 [11].

\begin{tabular}{cccccc}
\hline $\begin{array}{c}\text { Desert Locust } \\
\text { Episodes }\end{array}$ & $\begin{array}{c}\text { No. } \\
\text { Countries }\end{array}$ & Ha Sprayed & Duration & $\begin{array}{c}\text { Cost to } \\
\text { Donors }\end{array}$ & $\begin{array}{c}\text { Intervention } \\
\text { Timing }\end{array}$ \\
\hline $1986-1989$ & 23 & 25 million & 4 years & $\$ 310$ million & Late \\
$1992-1994$ & 18 & 4 million & 2 years & $\$ 18.8$ million & Moderate \\
$1997-1998$ & 7 & 430,000 & 7 months & $\$ 30,000$ & Early \\
$2003-2005$ & 20 & 13 million & 2.5 years & $\$ 35$ million & Late \\
$2007-2016^{\text {a }}$ & 22 & 1.8 million & 10 years & $<\$ 1$ million & Early \\
\hline
\end{tabular}

a Ten-year period involved numerous outbreak episodes. ${ }^{\mathrm{b}}$ US\$.

\subsection{Proaction}

Proaction is an intermediate response between reaction and outbreak prevention $[9,12,26,35,36]$. The progression of desert locust populations from recession to plague status is a continuum; outbreak prevention occurs at the initial stage, while later intervention during outbreaks is proactive. Although both terms refer to early interventions for averting plagues, the difference is in the timing. Conflation of outbreak prevention with proaction (i.e., [13,14]) obscures the important distinction between them $[4,9,11]$. Historical records show that the longer gregarious populations breed, the greater the risk of being overwhelmed by the locust situation and the greater the likelihood of reaching plague status $[4,11,25,28,37]$.

Proactive intercession against desert locusts is initiated based on an often ad hoc blend of estimated gregarizing populations, local control capabilities, political pressure, and gestalt [9]; there is no empirically calculated intervention threshold. The default is killing all gregarious nymphal bands and swarms [4], representing zero-tolerance. The best available approach is proaction (Figure 1) and, following the 1986-1989 plague, it has had different degrees of success $[4,8-11,20,25,38,39]$.

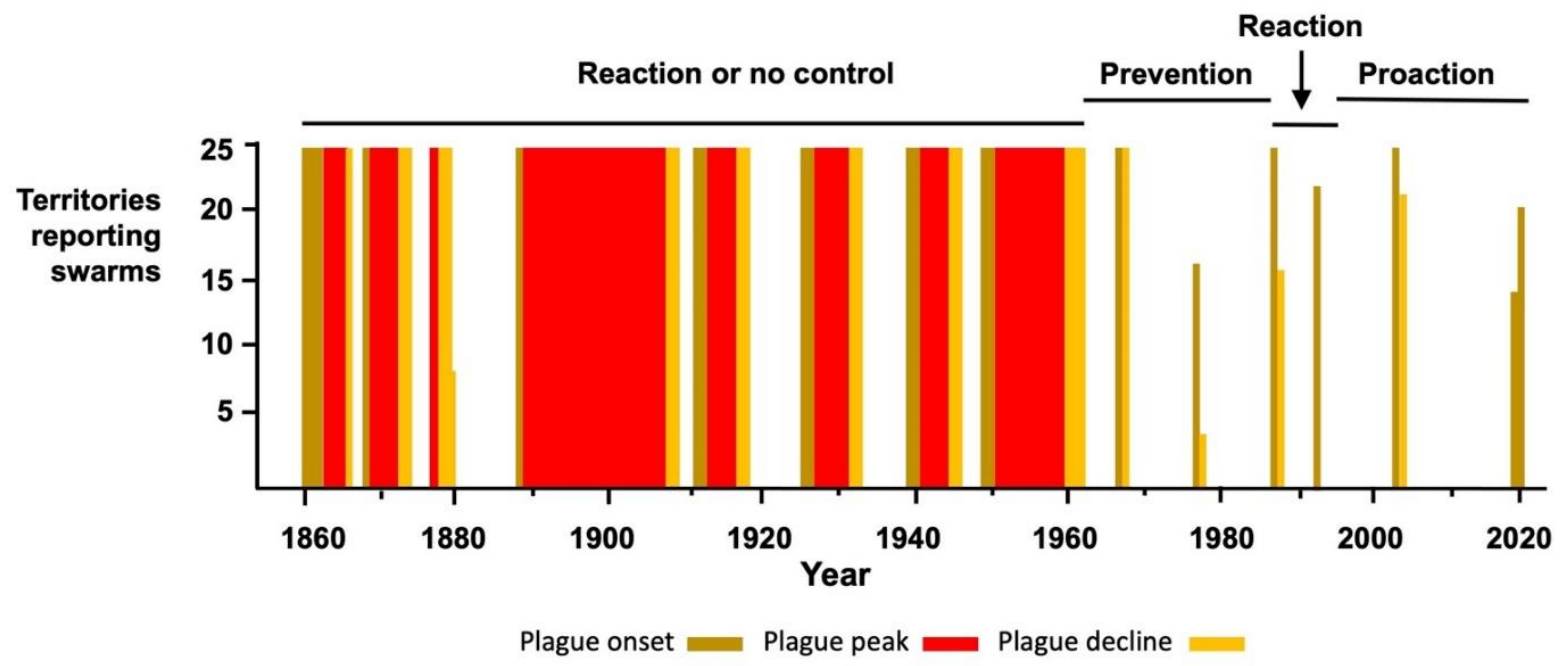

Figure 1. Bars represent years during which major desert locust activity (major upsurges and plagues) occurred (adapted and modified from 3), 1860-2020 (most recent upsurge extended past 2020); prevalent control approaches are indicated, prevention involved use of long-residual organochlorinated insecticides.

Desert locust episodes from 1986 to the present (2020) are relatively well-documented. Post-1970s, campaigns discontinued use of highly persistent, broad spectrum organochlorinated insecticides (e.g., DDT, dieldrin) due to environmental concerns [19,40]. Longresidual insecticides, however, were useful (Figure 1) for applying in limited swathes, or 
bands, on vegetation in breeding areas that killed nymphs crawling into those areas by direct contact and ingestion of treated foliage [25]. Early control of desert locust outbreaks was obviously weakened by the banning of dieldrin [25,41-43]. Control since the 1970s has relied almost exclusively on relatively short-residual insecticides, including malathion, propoxur, and some pyrethroids [19]. Contemporary inability to control nymphal bands using long residual prophylactic methods means that spraying must be spatially and temporally accurate. Reliance on short residual insecticides has resulted in the need to take more individual control actions against nymphal bands, as well as highly mobile adult swarms. This has increased areas sprayed and numbers of afflicted countries, and intensified dependence on international aid [11]. In terms of insecticide treated areas, the 1997-1998 outbreak, involving proaction, was only $1.7 \%$ and $3.3 \%$ the magnitude of the 1986-1989 plague and the 2003-2005 upsurges, respectively [11]. During the ten-year period 2007-2016, when there were no plagues (Figure 1) but numerous outbreaks, proaction likely contributed to limiting the magnitude of sprayed area, across all ten years, to $7.2 \%$ and $13.8 \%$ of the 1986-1989 and 2003-2005 episodes, respectively (Table 2) [11]. International aid supporting proaction against the $1997-1998$ outbreak was $0.01 \%$ and $0.3 \%$ of costs incurred during reactive 1986-1989 and 2003-2005 campaigns, respectively [11]. Accrued donor expenditures for 2007-2016 constituted only $0.1 \%$ and $2.9 \%$ of the 1986-1989 and 2003-2005 campaigns, respectively [11]. Furthermore, the proactive 1997-1998 campaign took just seven months, whereas the reactive campaigns persisted for $2.5-4$ years $[5,11,20]$.

Table 2. Numbers of countries infested, percentage of months in which proactive control occurred, area sprayed with insecticides, and number of times FAO Bulletin used "alarm" words to describe the desert situation, 2007-2016 (adapted from 11).

\begin{tabular}{ccccc}
\hline Year & $\begin{array}{c}\text { No. Countries } \\
\text { Infested }\end{array}$ & $\begin{array}{c}\text { \% Months with } \\
\text { Proactive Intervention }\end{array}$ & $\begin{array}{c}\text { Hectares } \\
\text { Sprayed }\end{array}$ & $\begin{array}{c}\text { Number of } \\
\text { Alarm Words a }\end{array}$ \\
\hline 2007 & 14 & 100 & 255,887 & 18 \\
2008 & 9 & 75 & 64,744 & 0 \\
2009 & 9 & 92 & 37,613 & 12 \\
2010 & 10 & 75 & 48,163 & 3 \\
2011 & 11 & 83 & 197,380 & 11 \\
2012 & 9 & 92 & 215,660 & 26 \\
2013 & 11 & 100 & 482,159 & 21 \\
2014 & 13 & 100 & 373,231 & 11 \\
2015 & 5 & 50 & 108,162 & 0 \\
2016 & 11 & 92 & 54,916 & 15 \\
\hline
\end{tabular}

a Alarm words: critical, extremely alarming, extremely/very serious, outbreak, potentially dangerous, potentially threatening, potentially very dangerous, serious, and threatening.

Belayneh [20] concluded that lack of proactive intervention in 2003-2005 allowed desert locust populations to breed until attaining upsurge status; the dynamic was mainly curbed by unfavorable climate-driven conditions. Had proactive control been conducted sufficiently early to spare $10 \%$ of the 2003-2005 agricultural losses, US\$226 million might have been conserved [20]. The cost of control during the 2003-2005 upsurge equaled projected costs of 170 years of proactive control [37].

Effective proaction hinges on the efficiency of outbreak suppression in breeding areas $[19,25,37,44]$. During the decade $2007-2016$, outbreaks were usually controlled within five months [11]. Proactive interventions helped to hasten return to recession status before outbreaks could expand into upsurges (Figure 1) [11]. Although not every outbreak during the ten years might have become an upsurge, some of them produced swarms that moved beyond breeding areas and reproduced in other regions (Table 2) [45] before being controlled. The Food and Agriculture Organization (FAO) monthly bulletins warned, commonly in ominous terms (Table 2), that desert locust populations and habitat conditions favored imminent development toward upsurges [11,45]. Claims that ten years of proactive strategy is riskier than reactive campaigns [13] have not been supported by events [11]. 


\subsection{Outbreak Prevention}

Outbreak prevention refers to intervention that is sufficiently early to avert the onset, and initial development, of gregarization before and when nymphs first amass in small patches and adults gather in loose groups $[9,10,12]$. The approach will eliminate a sufficient proportion of the population to suppress pheromone cues associated with crowding (crowding elicits positive feedback for building fully gregarious populations) that trigger gregarization [4,46-54]. Sustainable interference with semiochemical gregarization triggers can, hypothetically, maintain recession status indefinitely $[8,9,11,12]$. Although proaction is an improvement over reaction, an earlier, preventive, approach offers an even more efficient control option $[4,10,11,55]$. While outbreak prevention is the logical ultimate goal of contemporary research efforts, it has not yet been implemented without using long-residual organochlorinated insecticides or through sufficiently early detection and intervention, as was accomplished in Mauritania in 2009, and again several years later [56]. On the other hand, preventive locust control strategies had achieved success against some swarming species, such as the red locust, Nomadacris septemfasciata (Serville), in southern Africa [57], and the South American locust, Schistocerca cancellata (Serville) [17,58]. Assuming that outbreak prevention becomes possible, it is likely that proactive interventions will continue intermittently until prevention is sustainable. A proactive contingency capability will likely remain prudent, even when outbreak prevention is sustainable, to counter unforeseen gregarization events.

\section{Proaction: A Technological and Social Accomplishment}

Surveillance locates desert locust populations for control. Both surveillance and control have benefitted from technological advances, as has communication, which is essential for gathering data from afflicted countries, disseminating desert locust forecasts from the FAO, and intra- and interregional coordination.

\subsection{Surveillance}

Proactive intervention relies upon well-targeted, accurate, and quickly communicated surveillance information, particularly in areas prone to producing gregarious populations. The geographic foci of surveillance efforts can change over time depending upon several factors, including weather and greenness, and it is accomplished by multiple means involving different levels of technological sophistication $[5,8,11]$. Surveillance must be sustainable in order to produce routine reports during times of calm as well as site-specific, detailed reports contributing to national, regional, and international data bases to better understand population dynamics $[7,10,11,26,59]$. In general, information gathered by technologically sophisticated methods requires relatively low-technology ground verification in order to detect and characterize actual desert locust activity.

Technological improvements to surveillance began during the mid-1980s, including use of remote sensing imagery (particularly to assess cover by green vegetation and soil moisture) and climatic and weather data collection methods, both of which help to anticipate desert locust activity $[11,25,38,44,60-66]$. These factors, combined with historical data and field-based reports, identify where conditions are conducive to outbreaks $[8,10,11,15,59]$. Suspect areas can be monitored for incidence of gregarizing populations $[9,10,59]$ by scouts in terrestrial vehicles, and by obtaining reports from farmers, nomads, administrative authorities, militaries, and sometimes fire lookouts in the Atlas Mountains and rebel groups in contested territories [5,8,11,59]. Aerial surveillance (and control) is conducted, when possible, by the regional Desert Locust Control Organization for Eastern Africa (DCLO-EA), which has aircraft [67] (Saudi Arabia has its own aircraft). Field information is radioed to national ministries of agriculture that transmit reports by email and other electronic means to regional coordination centers and to the desert locust information service of FAO in Rome. Recently developed technology (elocust 3) [68] is used to transmit, in parallel, information to national locust units and to the Food and Agriculture Organization. The information is collated, synthesized, interpreted, and reported back to 
the afflicted and donor countries accompanied by desert locust activity forecasts. The value of technological advances for enhancing surveillance, communication, and forecasting is corroborated by successful proaction from 2007 through 2016 [11].

\subsection{Control}

Following the shift away from long-residual organochlorinated insecticides during the 1980s [3,40], use of conventional, synthetic, relatively short residual insecticides sprayed directly onto nymphal bands and settled swarms has been the only available control tactic $[10,25]$, excluding recent limited use of entomopathogens. Short residual insecticides are effective when desert locust populations are detected early and with sufficient accuracy to halt outbreaks. Currently used insecticides can also be applied as "barriers" against nymphal bands $[66,69,70]$, but this is not particularly efficacious for long-term prophylactic control. Selective insecticides, including insect growth regulators [25], might also be efficacious as barrier treatments, but they are unlikely to be more persistent than conventional insecticides. Entomopathogens are commercially available, and others are being evaluated $[45,66,71]$. In 2020, entomopathogens were applied to at least 10,845 ha in Somalia against desert locusts [72,73]. Other alternative tactics have not been reported [10,25].

Additional technological advances include ultra-low volume (ULV) spray equipment, now in routine aerial and terrestrial use against desert locusts [44,66]. ULV formulations are oil-based, reducing droplet evaporation such that only $0.5-1.0 \mathrm{~L}$ of the insecticide is needed per hectare [44], decreasing environmental contamination and costs of transportation, handling, and storage [11]. In addition, global positioning systems (GPS) technology improves precision of insecticide applications, enhances navigation to targets that are often located in vast, remote wilderness $[25,66]$, and reduces spurious environmental exposure to, and wastage of, insecticides. Research is underway to test the utility of unmanned aerial vehicles (UAV) or drones for desert locust detection and control.

\section{Outbreak Prevention: Salient Requirements}

The most important research goal now is arguably the development of a reasonably long-residual and environmentally benign control tactic that, whether chemical, biological, or other, is useful in a prophylactic context. Furthermore, the length of time constituting a reasonably long effective residual (days, weeks, months) should be established.

Because early intervention occurs within limited windows of opportunity, insecticide application timing is important even for reasonably long-residual tactics; hence, surveillance must be able to sustainably detect the onset of gregarization. It is not yet clear how this can be achieved, but it will rely, at least in part, on global information systems (GIS) imagery and weather information $[4,11]$. Outbreak prevention will require study of geo-historical desert locust survey and control to refine our knowledge of breeding and phase transformation in salient areas, such as has been accomplished in Mauritania and a few other countries $[15,59,74-76]$. Outbreak prevention will also entail use of empirical measurements that serve as triggers, or thresholds, for interventions $[4,46]$. It is likely that thresholds will have to be tailored for local conditions across time (e.g., seasonally) and in different areas [4]. An intervention threshold might be based on integrations of population density, food source abundance, and food source clumping which, in certain configurations, are associated with the initiation of gregarization $[4,46]$. In addition to using visual assessments of potentially gregarious desert locust activity as intervention threshold tools, it might be possible to develop a sensor for detecting semiochemicals associated with phase transformation as a cue to intervene.

Surveillance of population densities alone is inadequate for predicting gregarization because of differences between discrete desert locust habitats [4], which extend from Mauritania to India [11,17]. In western Africa, limited north-south movement of the intertropical convergence zone (ITCZ), which can be tracked, affects amounts of precipitation, and wind speed and direction, across the Sahel [15]. This provides a broad notion of where conditions are likely to favor desert locust population intensification, and, because swarms move 
downwind, projections about areas at risk of invasion [15]. A study in Mauritania and Morocco determined that a displacement cycle for swarms, largely based on ITCZ position, has a seasonal association, but this has not been confirmed for solitarious populations [15]. Population increases during recessions were associated with areas that received sufficient rainfall, which changes spatially over time because the ITCZ moves [15]. Following rainfall, persistence of water beneath the soil surface in wadis and other low-lying areas support flushes of vegetational growth [15]. The foliage supplies enough food to increase desert locust populations that, when conditions dry and the vegetated areas recede, results in crowding, semiochemical release, and gregarization [11,49]. Anticipation of gregarization based upon suitable breeding conditions has helped to protect northwestern Morocco from swarms developing south of the Atlas Mountains (e.g., the Sahel) since 1988 [15], a dividend of proaction [11]. Improved surveillance by ground teams can be attributed to superior map-based orientation, the effort invested, and training $[11,15]$. Heightened ability of ground surveillance teams to find desert locusts; however, might produce skewed information unless scouts also report where desert locusts were not observed [15]. Failure to record nonpopulated locations can result in inaccurate estimates of area-wide desert locust activity (it can also bias historical desert locust activity data) [15].

Habitat differences involve variables that might affect the propensity of a desert locust population to initiate gregarization. Understanding how food source clumping, community and individual plant structure and phenology, nutritional value, and availability influence population density is important for assessing the risk of gregarization $[4,46,52,75,77]$. To streamline scouting, areas that need to be searched are reduced by use of timely forecasts $[5,12]$, and although currently gathered information is sufficient to support proactive interventions, further refinements might better support outbreak prevention [4]. As an example, GIS technology has not yet been used to detect and map plant species that are particularly favorable to desert locust population increases [4] (GIS mapping of a selected lowgrowing plant species in Texas; however, has been accomplished to determine ixodid (hard tick) distribution [78]). Transect counts of desert locusts and important plant species might be useful for making risk assessments $[4,46]$ and associated intervention determinations.

Other relatively recent reports indicate that there are other facets of spatio-temporal aggregation patterns inherent to desert locust ecology that might be relevant to surveillance efforts. A field study conducted in Mauritania [77] confirmed observations that marching nymphal desert locust bands passed some plants and eventually roosted on patchily distributed trees near dusk, forming aggregations [79]. Maeno and Babah [77] found that gregarious bands of nymphs condensed on, and around, the largest tree in the local plant community; adults mostly roosted on large trees and substantial bushes $[80,81]$. Surveillance might also benefit from findings that indicate variability desert locust defensive responses to predators and likely to approaching terrestrial surveillance personnel (on foot and in vehicles). Whereas adult desert locusts usually take flight when temperatures exceed the minimum threshold for flight $\left(\approx 22{ }^{\circ} \mathrm{C}\right)[80,82]$, at cooler temperatures, locusts in low bushes tend to move into the middle of the bush upon which they are roosting in order to hide; individuals on taller plants ( $\geq 2 \mathrm{~m})$ tend to remain stationary [80].

\section{Impediments}

Lecoq [25] and Doré et al. [29] emphasized that impediments to proactive and preventive strategies require thorough analysis and documentation. Although some authors (e.g., $[13,14])$ have suggested that the sole obstacle has been funding shortfalls, the scope of impediments is considerably wider and more complex. The array of challenges confronting many afflicted countries has been fundamental to the development of plagues for $\geq 40$ years. Challenges that intertwine with and compound one another have been described [3-5,8,10,11,16,83]: unpreparedness [5,11,18,20,25,62,67], insecurity [11,83], remote, rugged terrain and poor infrastructure [8,11], environmental concerns $[11,18,19,40,67]$, political hindrances [3,5,8,16,20,62], dogmas and assumptions [11], and research impediments [11]. The negative impacts of many challenges can be mitigated by advances in tech- 
nology and appropriate funding. One notably intractable exception is insecurity $[11,83,84]$, which can cripple desert locust surveillance and control.

\section{Changing Priorities}

Major outbreak areas, and the ecological conditions and gregarization mechanism that initiate outbreaks, are known, and an early warning system of surveillance and reporting is in place $[3,4,11,36]$. Now that we have a substantially improved grasp of the desert locust's complex ecology, the next steps should focus to an increasing extent on the complexities of control systems governance $[3,85]$. The weakest link in desert locust control is unpreparedness due to problems with organization, coordination, logistics at international and national levels [3,4], and insecurity [83]. Unpreparedness is largely the result of inactive recessions when the complex web of interactions that enable control seizes up and donor funding declines $[16,86]$. Additionally, personnel turnover depletes trained cadres and institutional memory fades in the afflicted countries [16]. Hence, when proactive interventions hold desert locusts in the solitary phase for long periods, maintenance of surveillance and control capabilities declines, accompanied by loss of focus, equipment, insecticides, personnel, and expertise $[16,86]$.

To muster coherent early responses to dynamic desert locust episodes, regional and international cooperation must be well coordinated. Increasing preparedness will involve strengthening national locust control units and making coordination among national, bilateral, and multilateral stakeholders a sustainable priority [3]. At the urging of international aid agencies, the FAO instituted the Emergency Prevention System (EMPRES) in 1996 to operate in parts of the desert locust recession areas [3]. EMPRES aimed to increase the capabilities of afflicted countries, regional desert locust control organizations, and the FAO $[3,4,6,87]$. The program has coordinated the development and application of technologies, and training, that improved upon proactive control $[3,11]$. Because the issue of financial sustainability of desert locust control systems is of critical importance, an institutional framework providing for graduated mobilization of funding and sources, depending on the severity of the desert locust episode, has been suggested $[87,88]$. An initial effort to develop such a fund involves the Commission for Controlling the Desert Locust in the Western Africa Region (CLCPRO), based in Algiers, in 2016 developed a regional fund to proactively control desert locust invasions, endowed with $\approx 6.5$ million US dollars from member countries (Algeria, Burkina Faso, Chad, Libya, Mali, Mauritania, Morocco, Niger, Senegal, and Tunisia) [89,90]. A risk management plan, possibly including intervention thresholds, can be formulated prescribing coordinated stakeholder actions for different levels of desert locust activity [4]. Coordination must be strong at all times in order to maintain vigilance and early response capability during recessions [3,16]. Multi-agent modeling has been suggested as a way of better understanding stakeholder interactions and system responses [16].

\section{Conclusions: New Upsurge}

The most recent major desert locust upsurge became apparent during winter and spring 2020. The episode originated when heavy rains fell during the latter half of 2018 in the Rub al Khali, or Empty Quarter, of Saudi Arabia [90]. The resulting favorable breeding conditions supported three undetected generations [90], and in December, swarms spread elsewhere in Saudi Arabia, as well as to Yemen, Egypt, Eritrea, Sudan, and southwestern Iran, where breeding occurred (Figure 2) [91-93]. Control operations were conducted in Saudi Arabia, Iran, Eritrea, Egypt, and Sudan through spring 2019. Yemen, beset by armed conflict, and Iran mustered weak responses and swarms from Iran invaded the India-Pakistan border where three generations produced more swarms (Figure 2) [91]. Swarms from Yemen crossed the Red Sea to northern Somalia and Ethiopia (Figure 2), where breeding produced additional swarms [90]. Survey reports were not obtained from Somalia through spring 2019 [92-96], but it is likely that gregarious populations continued to arrive from Yemen and reproduce. During summer 2019, desert locust activity and 
control operations occurred in Ethiopia, Saudi Arabia, Iran, India, and Pakistan [96-98]. Surveillance remained weak in Somalia and Yemen, where gregarious populations were not controlled [97-99]. During fall and winter 2019-2020, desert locust activity resumed in Eritrea and Sudan, continued in Saudi Arabia, India, Pakistan, and, in December, Iran (Figure 2) [100-105]. Kenya was invaded (Figure 2) in December 2019, and infestations there intensified through February 2020, accompanied by control operations [104,105]. Furthermore, populations arriving from Saudi Arabia increased in Oman until, in the latter half of winter, intervention occurred [102-106]. Gregarious populations in Somalia and Yemen persisted while surveillance remained weak and control was limited [100-106]. During spring (March-June) 2020, infestations in Eritrea declined, while substantial gregarious populations and control operations continued in Ethiopia, Kenya, Oman, Saudi Arabia, Iran, Pakistan, and, by late spring, India [72,73,107]. Surveillance and control operations in Somalia and Yemen were spotty, but gregarious populations were likely to have been substantial $[72,73,107]$. During the episode, other countries were invaded and undertook control operations, particularly Iraq, Jordan, Kuwait and the United Arab Emirates, and infestations were comparatively light in Afghanistan, Bahrain, Djibouti, Libya, South Sudan, Tanzania, and Uganda (Table 3) [72,73,92-108]. During the first two years of the episode, June 2018 to June 2020, swarms were observed in $\geq 22$ countries, and spray operations occurred in $\geq 19$ countries, covering $>2,792,840$ ha (Table 3 ) [72,73,92-107].

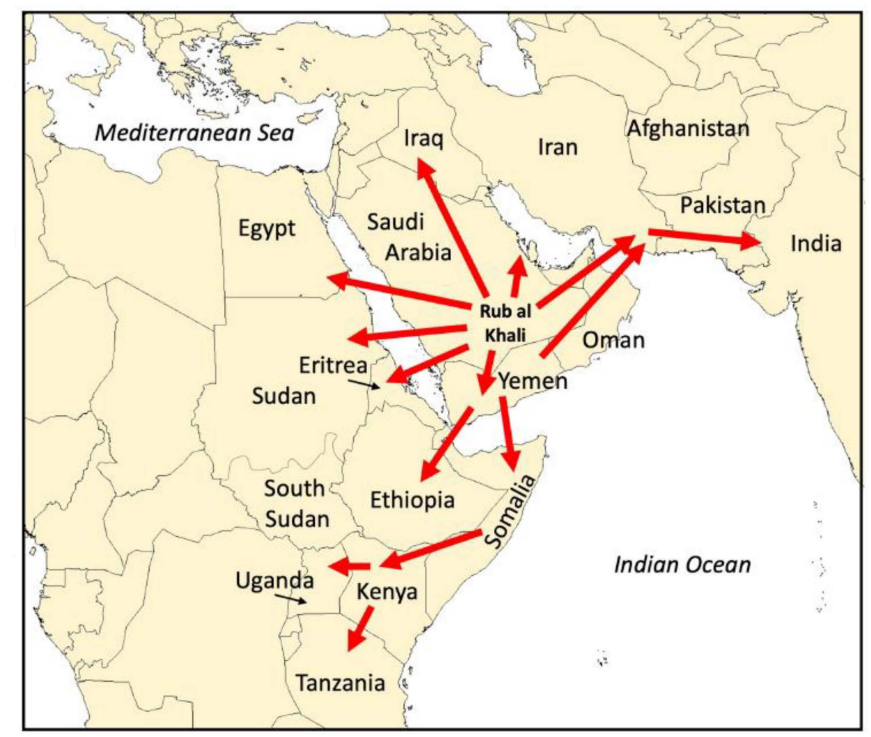

Figure 2. Generalized movements of major gregarious desert locust swarms, beginning June 2018 in the Rub al Khali of Saudi Arabia, moving out from the Rub al Khali by December 2018 and beyond Saudi Arabia through June 2020 [72,73,90-106].

We suggest that, had the initial outbreak in the Rub al Khali of Saudi Arabia been detected in summer 2018, swarms might not have reached Yemen, the Red Sea coast of Africa, and parts of Iran. While substantial control operations commenced December 2018 in Saudi Arabia, Egypt, Eritrea, and Sudan, the capabilities of Yemen and Somalia, both hobbled by insecurity, harbored and produced swarms that invaded other countries, and the initially weak response in Iran permitted swarms to move to Pakistan and India [91]. Because control was conducted in most of the other afflicted countries (Table 3), it is likely that once Saudi Arabia had begun to control its desert locusts, Somalia and Yemen continued to drive expansion and intensification. Effective surveillance and control in those two countries would have eliminated further spread in concert with the substantial control operations that occurred in Egypt, Eritrea, Ethiopia, and Sudan, and some other countries adjacent to them (e.g., Tanzania, Uganda). Similarly, effective early intervention in Iran would have spared Pakistan and India. The episode illustrates how a chain of worsening 
desert locust population events resulted because of unpreparedness and insecurity in a few countries [109].

Table 3. Countries invaded by desert locust swarms and areas sprayed with insecticides, December 2018-June 2020 [72,91-106].

\begin{tabular}{cc}
\hline Country & Area (ha) Sprayed \\
\hline Afghanistan & 20 \\
Bahrain & 34 \\
Djibouti & 0 \\
Egypt & 19,802 \\
Eritrea & 93,586 \\
Ethiopia & 288,205 \\
India & 427,233 \\
Iran & 887,657 \\
Iraq & 2610 \\
Jordan & 2900 \\
Kenya & 102,342 \\
Kuwait & 15,653 \\
Libya & 70 \\
Oman & 13,164 \\
Pakistan & 453,892 \\
Saudi Arabia & 402,881 \\
Somalia & 26,845 \\
South Sudan & 0 \\
Tanzania & 0 \\
Uganda & 607 \\
United Arab Emirates & 5904 \\
Yemen & 49,435 \\
Total: 22 & Total: 2,792,840 \\
\hline &
\end{tabular}

The episode also demonstrates that proactive interventions, which occurred in many of the afflicted countries, impeded significant spread beyond their borders [72,73,92-107]. Once gregarious populations arrived in India and Pakistan, for example, relatively few swarms escaped those two countries, and the same is true for Egypt, Eritrea, Ethiopia, and Sudan. Saudi Arabia, the initially unprepared source of the upsurge, could not avert movement into Bahrain, Iraq, Kuwait, Oman, United Arab Emirates, Yemen, and likely parts of the Red Sea coast of Africa. A timely proactive approach (or, hypothetically, an outbreak prevention approach) in the Rub al Khali, a relatively limited area, would have pre-empted the possibility of an upsurge.

Based upon the advantages of early intervention, stakeholders must recognize the difference between proaction and outbreak prevention to distinguish intermediate from ultimate goals. While proaction has been successfully implemented starting in the 1990s (Figure 1) $[4,9,11,12]$, a new approach to outbreak prevention that does not rely on environmentally persistent, broad-spectrum pesticides has not yet materialized. Advances that might contribute toward a viable outbreak prevention strategy, however, continue to unfold. Although surveillance and control were weak in Somalia, entomopathogens were applied there on at least two occasions [72,73], representing a step toward alternative, increasingly environmentally benign control, and possibly toward development of persistent formulations for prophylactic outbreak prevention. We also suggest that proaction and outbreak prevention require more smoothly operating national and regional organizations dedicated to early intervention, technical and funding mechanisms that provide sustainable support during recessions and gregarious episodes, heightened sustained vigilance, alleviation of impediments, and, with particular regard to armed conflict, some luck, even when mitigation measures are available [84]. 
Author Contributions: Conceptualization, A.T.S.; methodology, A.T.S., M.A.O.B.E., M.L. and K.O.M.; software, A.T.S. and M.L.; validation, A.T.S., M.A.O.B.E., M.L. and K.O.M.; formal analysis, A.T.S. and M.L.; investigation, A.T.S., M.A.O.B.E., M.L. and K.O.M.; resources, A.T.S. and M.L.; data curation, A.T.S. and M.L.; writing-original draft preparation, A.T.S.; writing-review and editing, A.T.S., M.A.O.B.E., M.L. and K.O.M.; visualization, A.T.S. and M.L.; and supervision, A.T.S. All authors have read and agreed to the published version of the manuscript.

Funding: This research received no external funding.

Institutional Review Board Statement: Not applicable.

Informed Consent Statement: Not applicable.

Data Availability Statement: Data sharing not applicable.

Conflicts of Interest: The authors declare no conflict of interest.

Disclaimer: Mention of trade names or commercial products in this publication is solely for the purpose of providing specific information and does not imply recommendation or endorsement by the U.S. Department of Agriculture. USDA is an equal opportunity provider and employer.

\section{References}

1. Uvarov, B.P. A revision of genus Locusta (= Pachytylus Fieb) with a new theory as to the periodicity and migrations of locusts. Bull. Entomol. Res. 1921, 12, 135-163. [CrossRef]

2. International War on Locusts. Nature 1938, 142, 565. [CrossRef]

3. Lecoq, M. Desert locust management: From ecology to anthropology. J. Orthopt. Res. 2005, 14, 179-186. [CrossRef]

4. Sword, G.A.; Lecoq, M.; Simpson, S.J. Phase polyphenism and preventative locust management. J. Insect Physiol. $2010,56,949-957$. [CrossRef] [PubMed]

5. Showler, A.T.; Potter, C.S. Synopsis of the desert locust, Schistocerca gregaria (Forskål), plague 1986-1989 and the concept of strategic control. Am. Entomol. 1991, 37, 106-110. [CrossRef]

6. FAO (Food and Agriculture Organization of the United Nations). Annual Report 1999. Emergency Prevention System for Transboundary Animal and Plant Pests and Diseases. Desert Locust Central Region Programme; FAO: Rome, Italy, 1999. Available online: http:/ / www.fao.org/ag/locusts/oldsite/PDFs/meetings/EMPRES99e.pdf (accessed on 29 October 2020).

7. FAO (Food and Agriculture Organization of the United Nations). Emergency Prevention System (EMPRES) for Transboundary Animal and Plant Pests and Diseases (Desert Locust Component), Central Region. Summary Report of the Evaluation Mission; FAO: Rome, Italy, 2003. Available online: http:/ / www.fao.org/3/a-bd101e.pdf (accessed on 29 October 2020).

8. Showler, A.T. Locust outbreak in Africa and Asia, 1992-1994. Am. Entomol. 1995, 41, 179-185. [CrossRef]

9. Showler, A.T. Proaction: Strategic framework for today's reality. In New Strategies in Locust Control; Krall, S., Peveling, R., Ba Diallo, D., Eds.; Birkhauser: Berlin, Germany, 1997; pp. 461-465. [CrossRef]

10. Showler, A.T. A summary of control strategies for the desert locust, Schistocerca gregaria (Forskål). Agric. Ecosyst. Environ. 2002, 90, 97-103. [CrossRef]

11. Showler, A.T. Desert locust control: The effectiveness of proactive interventions and the goal of outbreak prevention. Am. Entomol. 2018, 65, 180-191. [CrossRef]

12. Babah, M.A.O. Strategy for controlling the desert locust in Mauritania. In New strategies in Locust Control; Krall, S., Peveling, R., Ba Diallo, D., Eds.; Birkhauser: Berlin, Germany, 1997; pp. 487-491. [CrossRef]

13. Van Huis, A.; Cressman, K.; Magor, J.L. Preventing desert locust plagues: Optimizing management interventions. Entomol. Exp. Appl. 2007, 122, 191-214. [CrossRef]

14. Magor, J.I.; Lecoq, M.; Hunter, D.M. Preventive control and desert locust plagues. Crop Prot. 2008, 27, 1527-1533. [CrossRef]

15. Piou, C.; Bacar, M.H.J.; Babah, M.A.O.; Chiharane, J.; Ghaout, S.; Cisse, S.; Lecoq, M.; Halima, T.B. Mapping the spatiotemporal distributions of the desert locust in Mauritania and Morocco to improve preventive management. Basic Appl. Ecol. 2017, $25,37-47$. [CrossRef]

16. Gay, P.M.; Lecoq, M.; Piou, C. Improving preventive locust management: Insights from a multi-agent model. Pest Manag. Sci. 2018, 74, 46-58. [CrossRef]

17. Steedman, A. Locust Handbook; Overseas Development Natural Resources Institute: London, England, 1988.

18. United States Congress, Office of Technology Assessment. A Plague of Locusts; Special Report, OTA-F-450; Government Printing Office: Washington, DC, USA, 1990. Available online: https:/ / ota.fas.org/reports/9001.pdf (accessed on 29 October 2020).

19. Showler, A.T. Desert locust control, public health, and environmental sustainability in North Africa. In The North African Environment at Risk; Swearingen, W.D., Bencherifa, A., Eds.; Westview Press: Boulder, CO, USA, 1995; pp. $217-239$.

20. Belayneh, Y.T. Acridid pest management in the developing world: A challenge to the rural population, a dilemma to the international community. J. Orthopt. Res. 2005, 14, 187-195. Available online: https://www.jstor.org/stable/3657127 (accessed on 15 October 2020). [CrossRef] 
21. Brader, L.; Djibo, H.; Faye, F.G.; Ghaout, S.; Lazar, M.; Luzietoso, P.N.; Babah, M.A.O. Multilateral Evaluation of the 200305 Desert Locust Campaign; Food and Agriculture Organization of the United Nations: Rome, Italy, 2006. Available online: http:/ / www.fao.org/ag/locusts/common/ecg/1913/en/DesertLocustEvalReportE.pdf (accessed on 3 November 2020).

22. Krall, S.; Herok, C. Economics of desert locust control. In New Strategies in Locust Control; Krall, S., Peveling, R., Ba Diallo, D., Eds.; Birkhauser: Berlin, Germany, 1997; pp. 401-413. [CrossRef]

23. Lockwood, J.A. Locust: The Devastation, Rise and Mysterious Disappearance of the Insect That Shaped the American Frontier; Basic Books: New York, NY, USA, 2004.

24. Krall, S. Importance of locusts and grasshoppers for determining crop losses. In New Trends in Locust Control: Ecotoxicology, Botanicals, Pathogens, Attractants, Hormones, Pheromones, Remote Sensing; Krall, S., Wilps, H., Eds.; Deutsche Gesellchaft für Technische Zusammenarbeit (GTZ): Eschborn, Germany, 1994; pp. 7-22.

25. Lecoq, M. Recent progress in desert and migratory locust management in Africa: Are preventative actions possible? J. Orthopt. Res. 2001, 10, 277-291. [CrossRef]

26. Rowley, J.; Bennet, O. Grasshoppers and Locusts: The Plague of the Sahel; Panos dossier, the Panos Institute: London, England, 1993.

27. Joffe, S. Economics and Policy Issues in Desert Locust Management: A Preliminary Analysis; Report no. AGPP/DL/TSD/27; Food and Agriculture Organization of the United Nations: Rome, Italy, 1998; 27p. Available online: http:/ /www.fao.org/ag/locusts/ oldsite/PDFs/TS27p1.pdf (accessed on 3 November 2020).

28. FAO (Food and Agriculture Organization of the United Nations). Biology and Behaviour. Desert Locust Guidelines; FAO: Rome, Italy, 2001. Available online: http:/ /www.fao.org/ag/locusts/common/ecg/347_en_DLG1e.pdf (accessed on 29 October 2020).

29. Doré, A.; Babah, M.A.O.; Barbier, M.; Lecoq, M. Rethinking organization and governance for surveillance and risk management of desert locust outbreaks. In Proceedings of the 9th International Conference of the Orthopterists' Society, Canmore, AB, Canada, 14-18 August 2005; p. 33. Available online: http:/ / publications.cirad.fr/une_notice.php?dk=528208 (accessed on 29 October 2020).

30. Moussaoui, M. Etude sur L'intérêt Economique de la Lutte Préventive Contre le Criquet Pèlerin; FAO: Rome, Italy, 2010.

31. De Vreyer, P.; Guilbert, N.; Mesple-Sompsa, S. Impact of natural disasters on education outcomes: Evidence from the 1987-89 locust plague in Mali. J. Afr. Econ. 2014, 24, 57-100. [CrossRef]

32. FAO (Food and Agriculture Organization of the United Nations). Global Information and Early Warning System on Food and Agriculture World Food Program: Special Report, FAO/WFP Crop and Food Supply Assessment Mission to Mauritania with Special Focus on Losses Due to the Desert Locust, 21 December 2004; FAO: Rome, Italy, 2004. Available online: https:/ / reliefweb.int/report/mauritania/ faowfp-crop-and-food-supply-assessment-mission-mauritania-special-focus-losses-due (accessed on 5 November 2020).

33. FAO (Food and Agriculture Organization of the United Nations). Global Information and Early Warning System on Food and Agriculture World Food Program: Special Report, FAO/WFP Crop and Food Supply Assessment Mission to Mali with Special Focus on Losses Due to the Desert Locust, 21 December 2004; FAO: Rome, Italy, 2004. Available online: https:/ / documents.wfp.org/stellent/ groups/public/documents/ena/wfp043774.pdf?iframe (accessed on 5 November 2020).

34. FAO (Food and Agriculture Organization of the United Nations). Global Information and Early Warning System on Food and Agriculture World Food Program: Special Report, FAO/WFP Crop and Food Supply Assessment Mission to Niger with Special Focus on Losses Due to the Desert Locust, 21 December 2004; FAO: Rome, Italy, 2004. Available online: http:/ /www.fao.org/3/J3969e/J3969e00.htm (accessed on 5 November 2020).

35. Lecoq, M.; Duranton, J.F.; Rachadi, T. Towards an integrated strategy for the control of the desert locust. In New Strategies in Locust Control; Krall, S., Peveling, R., Ba Diallo, D., Eds.; Birkhauser: Berlin, Germany, 1997; pp. 467-473. [CrossRef]

36. Lecoq, M. Desert locust threat to agricultural development and food security and FAO's international role in its control. Arab J. Plant Prot. 2003, 21, 188-193.

37. FAO (Food and Agriculture Organization of the United Nations). The FAO Commission for controlling the Desert Locust in South-West Asia: A celebration of 50 Years; FAO: Rome, Italy, 2014. Available online: http:/ / www.fao.org/3/a-i4202e.pdf (accessed on 29 October 2020).

38. Latchininsky, A.V.; Sivanpillai, R. Locust habitat monitoring and risk assessment using remote sensing and GIS technologies. In Integrated Management of Arthropod Pests and Insect Borne Diseases; Ciancio, A., Mukerji, K.G., Eds.; Springer: Dordrecht, The Netherlands, 2010; pp. 163-188. [CrossRef]

39. FAO (Food and Agriculture Organization of the United Nations). Desert Locust Outbreak in Yemen, June 2013-February 2014; FAO: Rome, Italy, 2014. Available online: http:/ / www.fao.org/ag/locusts/en/archives/1032/2136/YEM2013/index.html (accessed on 29 October 2020).

40. Wiktelius, S.; Edwards, S. Organochlorine insecticide residues in Africa fauna: 1971-1995. Rev. Environ. Contamin. Toxicol. 1997, 151, 1-37.

41. Roy, J. Histoire d'un Siècle de Lutte Anti-Acridienne en Afrique. Contributions de la France; L'Harmatan: Paris, France, 2001.

42. Skaf, R. A story of a disaster: Why locust plagues are still possible. Disasters 1988, 12, 122-126. [CrossRef]

43. Skaf, R.; Popov, G.B.; Roffey, J. The Desert Locust: An international challenge. Philos. T. R. Soc. B 1990, 328, 525-538.

44. Sharma, A. Locust control management: Moving from traditional to new technologies-An empirical analysis. Entomol. Ornithol. Herpetol. 2015, 4, 141. [CrossRef]

45. FAO (Food and Agriculture Organization of the United Nations). Desert Locust Watch. 2017. Available online: http://www.fao. org/ag/locusts/en/info/info/index.html (accessed on 3 November 2020). 
46. Cisse, S.; Ghaout, S.; Mazih, A.; Babah, M.O.A.; Benahi, S.; Piou, C. Effect of vegetation on density thresholds of adult desert locust gregarization from survey data in Mauritania. Entomol. Exper. Applic. 2013, 149, 159-165. [CrossRef]

47. Bouïchi, A.; Simpson, S.J.; Roessingh, P. The influence of environmental microstructure on the behavioural phase state of distribution of the desert locust Schistocerca gegaria. Physiol. Entomol. 1996, 21, 247-256. [CrossRef]

48. McCafferty, A.R.; Simpson, S.J.; Islam, M.; Roessingh, P. A gregarizing factor present in the egg pod foam of the desert locust Schistocerca gregaria. J. Exp. Biol. 1998, 201, 347-363.

49. Simpson, S.J.; McCafferty, A.R.; Hägele, B. A behavioural analysis of phase change in the desert locust. Biol. Rev. 1999, 74, 461-480. [CrossRef]

50. Despland, E.; Simpson, S.J. The role of food distribution and nutritional quality in behavioral phase change in the desert locust. Anim. Behav. 2000, 59, 643-652. [CrossRef]

51. Despland, E.; Simpson, S.J. Small-scale vegetation patterns in the parental environment influence the phase state of hatchlings of the desert locust. Physiol. Entomol. 2000, 25, 74-81. [CrossRef]

52. Babah, M.A.O.; Sword, G.A. Linking locust gregarization to local resource distribution patterns across a large spatial scale. Environ. Entomol. 2004, 33, 1577-1583. [CrossRef]

53. Rodgers, S.M.; Matheson, T.; Anstey, M.; Simpson, S.J. Early induction of behavioural phase change in the desert locust. In Proceedings of the 9th International Conference of the Orthopterists' Society, Canmore, AB, Canada, 14-18 August 2005 ; p. 71. Available online: https://ybo.ewq.mybluehost.me/wp-content/uploads/2018/10/Metaleptea_9th_ICO_Canada.pdf (accessed on 3 November 2020).

54. Pener, M.P.; Simpson, S.J. Locust phase polyphenism: An update. Adv. Insect Physiol. 2009, 36, 1-286. [CrossRef]

55. Babah, M.A.O. Brief overview on the desert locust problem. Tunis. Plant Prot. J. 2011, 6. Available online: https://www.jircas.go. jp/sites/default/files/publication/proceedings/2012-session-41_0.pdf (accessed on 29 October 2020).

56. Improved Ways to Prevent the Desert Locust in Mauritania and the Sahel; World Bank: Washington, DC, USA, 2010. Available online: https:/ / www.worldbank.org/en/news/feature/2010/01/07/improved-ways-to-prevent-the-desert-locust-in-mauritaniaand-the-sahel (accessed on 5 February 2021).

57. Byaruhanga, E.K. Developments in the strategy of Red Locust plague prevention in the fifty-year history of the International Red Locust Control Organisation for Central and Southern Africa. Int. J. Trop. Insect Sci. 1999, 19, 259-264. [CrossRef]

58. Hunter, D.M.; Cosenzo, E.L. The origin of plagues and recent outbreaks of the South American locust Schistocerca cancellata (Orthoptera: Acrididae) in Argentina. Bull. Entomol. Res. 1990, 80, 295-300. [CrossRef]

59. Babah, M.O.A. Biogéographie du Criquet Pèlerin Schistocerca Gregaria Forskål, 1775: Identification, Caracterisation et Originalité d'un foyer Grégarigène en Mauritanie Centrale; Hermann: Paris, France, 2010.

60. Tucker, C.J.; Hielkema, J.U.; Roffey, J. The potential of satellite remote sensing of ecological conditions for survey and forecasting desert locust activity. Int. J. Remote Sens. 1985, 6, 127-138. [CrossRef]

61. Ceccato, P. Operational early warning system using SPOT-VEGETATION and TERRA-MODIS to predict desert locust outbreaks. In Proceedings of the 2nd International SPOT-VEGETATION User's Conference; Veroustraete, F., Bartholomé, E., Eds.; European Commission Official Publication of the European Communities: Brussels, Belgium, 2005. [CrossRef]

62. Ceccato, P.; Cressman, K.; Giannini, A.; Trzaska, S. The desert locust upsurge in West Africa (2003-2005): Information on the desert locust early warning system and the prospects for seasonal climate forecasting. Int. J. Pest Manag. 2007, 53, 7-13. [CrossRef]

63. Renier, C.; Waldner, F.; Jacques, D.C.; Babah, M.O.A.; Cressman, K.; Defourny, A. A dynamic vegetation senescence indicator for near-real-time desert locust habitats monitoring with MODIS. Remote Sens. 2015, 7, 7545-7570. [CrossRef]

64. Waldner, F.; Babah, M.A.O.; Cressman, K.; Defourny, P. Operational monitoring of the desert locust habitat with Earth observation: An assessment. Int. J. Geo-Inform. 2015, 4, 2379-2400. [CrossRef]

65. Escorihuela, M.J.; Merlin, O.; Stefan, V.; Moyano, G.; Eweys, O.A.; Zribi, M.; Kamara, S.; Benahi, A.S.; Babah Ebbe, M.A.; Chihrane, J.; et al. SMOS based high resolution soil moisture estimates for desert locust preventive management. Remote Sens. Appl. Soc. Environ. 2018, 11, 140-150. [CrossRef]

66. Zhang, L.; Lecoq, M.; Latchininsky, A.; Hunter, D. Locust and grasshopper management. Annu. Rev. Entomol. 2019, 64, 15-34. [CrossRef] [PubMed]

67. Appleby, G.; Settle, W.; Showler, A.T. Mid-Term Evaluation of the African Emergency Locust/Grasshopper Assistance (AELGA) Project; Tropical Research and Development: Gainesville, FL, USA, 1989.

68. Cressman, K.; Van der Elstraeten, A.; Pedrick, C. Elocust3: An Innovative Tool for Crop Pest Control; Food and Agriculture Organization of the United Nations: Rome, Italy, 2018. Available online: www.fao.org/3/a-i6058e.pdf (accessed on 29 October 2020).

69. Cooper, J.F.; Coppen, G.D.A.; Dobson, H.M.; Rakotonandrasana, A.; Scherer, R. Sprayed barriers of diflubenzuron (ULV) as a control technique against marching hopper bands of a migratory locust Locusta migratoria capito (Sauss.) (Orthoptera: Acrididae) in southern Madagascar. Crop Prot. 1995, 14, 137-143. [CrossRef]

70. Rachadi, T.; Foucart, A. Barrier treatment of fipronil for controlling hopper bands of desert locust infesting a large area in Mauritania. Int. J. Pest Manag. 1999, 45, 263-273. [CrossRef]

71. Lomer, C.J.; Bateman, R.P.; Johnson, D.L.; Langwald, J.; Thomas, M. Biological control of locusts and grasshoppers. Annu. Rev. Entomol. 2001, 46, 667-702. [CrossRef] 
72. FAO (Food and Agriculture Organization of the United Nations). Desert Locust Bulletin, 4 May 2020; No. 499; FAO: Rome, Italy, 2020. Available online: http:/ / www.fao.org/ag/locusts/common/ecg/2551/en/DL499e.pdf (accessed on 3 November 2020).

73. FAO (Food and Agriculture Organization of the United Nations). Desert Locust Bulletin, 4 June 2020; No. 500; FAO: Rome, Italy, 2020. Available online: http://www.fao.org/ag/locusts/common/ecg/2555/en/DL500e.pdf (accessed on 3 November 2020).

74. Mahjoub, N. Le problème du criquet pèlerin et les perspectives de sa résolution. Nat. Faune 1988, 4, 16-20.

75. Woldewahid, G.; van der Werf, W.; van Huis, A.; Stein, A. Spatial distribution of populations of solitarious adult desert locust (Schistocerca gregaria Forsk.) on the coastal plain of Sudan. Agric. Forest Entomol. 2004, 6, 181-191. [CrossRef]

76. Lazar, M.; Piou, C.; Doumandji-Mitiche, B.; Lecoq, M. Importance of solitarious Desert locust population dynamics: Lessons from historical survey data in Algeria. Entomol. Exp. Appl. 2016, 161, 168-180. [CrossRef]

77. Maeno, K.O.; Ould Babah Ebbe, M.A. Aggregation site choice by gregarious nymphs of the desert locust, Schistocerca gregaria, in the Sahara Desert of Mauritania. Insects 2018, 9, 99. [CrossRef] [PubMed]

78. Showler, A.T.; Osbrink, W.L.A.; Abrigo, V.; Phillips, P.I. Relationships of salinity, relative humidity, mud flat fiddler crabs, ants, and sea ox-eye daisy with ixodid distribution and egg survival on the South Texas coastal plains. Environ. Entomol. 2019, 48, 733-746. [CrossRef] [PubMed]

79. Ellis, P.E.; Ashall, C. Field studies on diurnal behaviour, movement and aggregation in the desert locust (Schistocerca gregaria Forskål). Anti-Locust Bull. 1957, 25, 1-103.

80. Maeno, K.O.; Ould Ely, S.; Ould Mohamed, S.; Jaavar, M.E.H.; Nakamura, S.; Ould Babah Ebbe, M.A. Defence tactics cycle with diel microhabitat choice and body temperature in the desert locust, Schistocerca gregaria. Ethology 2019, 125, 250-261. [CrossRef]

81. Maeno, K.O.; Ould Ely, S.; Ould Mohamed, S.; Jaavar, M.E.H.; Ould Babah Ebbe, M.A. Adult desert locust swarms, Schistocerca gregaria, preferentially roost in the tallest plants at any given site in the Sahara Desert. Agronomy 2020, 10, 1923. [CrossRef]

82. Maeno, K.O.; Ould Ely, S.; Ould Mohamed, S.; Jaavar, M.E.H.; Nakamura, S.; Ould Babah Ebbe, M.A. Behavioral plasticity in anti-predator defense in the desert locust. J. Arid. Environ. 2018, 158, 47-50. [CrossRef]

83. Showler, A.T. The importance of armed conflict in the desert locust recession distribution, 1986-2002. J. Orthopt. Res. 2003, 12, 127-133. [CrossRef]

84. Showler, A.T.; Lecoq, M.; Babah, M.A.O.B. Incidence and ramifications of armed conflict in countries with major desert locust breeding areas. Agronomy 2021, 11, 114. [CrossRef]

85. Doré, A.; Barbier, M.; Lecoq, M.; Ould Babah, M.A. Prévention des invasions de criquets pèlerins: Analyse socio-technique d'un dispositif de gestion du risque. Cah. Agric. 2008, 17, 457-464. [CrossRef]

86. Lecoq, M. Lecoq, M. Le Criquet pèlerin. Enseignements de la dernière invasion et perspectives offertes par la biomodélisation. In La Lutte Anti-Acridienne; Essaid, A., Ed.; AUPELF-UREF, John Libbey Eurotext: Paris, France, 1991; pp. 71-98.

87. Martini, P.; Lecoq, M.; Soumaré, L.; Chara, B. Proposition de Programme de Lutte Contre le Criquet Pèlerin dans la Partie Occidentale de Son Aire D’habitat; Rapport 9963/F; FAO: Rome, Italy, 1998. Available online: http:/ /www.fao.org/ag/locusts/oldsite/PDF/ meetings/EMPRESwest98f.pdf (accessed on 20 October 2020).

88. Deshormes, A. Institutional Study to Enhance the Roles and Responsibilities of the Desert Locust Control Commissions Established under Article XIV. Financial Governance Final Report; Food and Agriculture Organization of the United Nations: Rome, Italy, 2011. Available online: http:/ / www.fao.org/ag/locusts/common/ecg/2148/en/Financial_Governance_Report_E.pdf (accessed on 20 October 2020).

89. FAO (Food and Agriculture Organization of the United Nations). Programme EMPRES en Région Occidentale; FAO: Rome, Italy, 2016. Available online: http:/ / www.clcpro-empres.org (accessed on 5 November 2020).

90. FAO (Food and Agriculture Organization of the United Nations). Evaluation Final de la Phase II (2014-2017) du Programme EMPRES/Composante Criquet Pèlerin en Région Occidentale (EMPRES-RO); FAO: Rome, Italy, 2018. Available online: http:/ / www. fao.org/3/ca4005fr/ca4005fr.pdf (accessed on 5 November 2020).

91. FAO (Food and Agriculture Organization of the United Nations). Current Upsurge (2019-2020). Desert Locust Watch. 2020. Available online: http://www.fao.org/ag/locusts/en/info/2094/index.html (accessed on 3 November 2020).

92. FAO (Food and Agriculture Organization of the United Nations). Desert Locust Bulletin, 9 January 2019; No. 483; FAO: Rome, Italy, 2019. Available online: http:/ /www.fao.org/ag/locusts/common/ecg/2455/en/DL483e.pdf (accessed on 3 November 2020).

93. FAO (Food and Agriculture Organization of the United Nations). Desert Locust Bulletin, 4 February 2019; No. 484; FAO: Rome, Italy, 2019. Available online: http://www.fao.org/ag/locusts/common/ecg/2462/en/DL484e.pdf (accessed on 3 November 2020).

94. FAO (Food and Agriculture Organization of the United Nations). Desert Locust Bulletin, 4 March 2019; No. 485; FAO: Rome, Italy, 2019. Available online: http:/ /www.fao.org/ag/locusts/common/ecg/2468/en/DL485e.pdf (accessed on 3 November 2020).

95. FAO (Food and Agriculture Organization of the United Nations). Desert Locust Bulletin, 3 April 2019; No. 486; FAO: Rome, Italy, 2019. Available online: http:/ / www.fao.org/ag/locusts/common/ecg/2471/en/DL486e.pdf (accessed on 3 November 2020).

96. FAO (Food and Agriculture Organization of the United Nations). Desert Locust Bulletin, 3 May 2019; No. 487; FAO: Rome, Italy, 2019. Available online: http:/ /www.fao.org/ag/locusts/common/ecg/2472/en/DL487e.pdf (accessed on 3 November 2020).

97. FAO (Food and Agriculture Organization of the United Nations). Desert Locust Bulletin, 5 June 2019; No. 488; FAO: Rome, Italy, 2019. Available online: http:/ / www.fao.org/ag/locusts/common/ecg/2475/en/DL488e.pdf (accessed on 3 November 2020).

98. FAO (Food and Agriculture Organization of the United Nations). Desert Locust Bulletin, 4 July 2019; No. 489; FAO: Rome, Italy, 2019. Available online: http:/ /www.fao.org/ag/locusts/common/ecg/2480/en/DL489e.pdf (accessed on 3 November 2020). 
99. FAO (Food and Agriculture Organization of the United Nations). Desert Locust Bulletin, 2 August 2019; No. 490; FAO: Rome, Italy, 2019. Available online: http://www.fao.org/ag/locusts/common/ecg/2482/en/DL490e.pdf (accessed on 3 November 2020).

100. FAO (Food and Agriculture Organization of the United Nations). Desert Locust Bulletin, 3 September 2019; No. 491; FAO: Rome, Italy, 2019. Available online: http://www.fao.org/ag/locusts/common/ecg/2483/en/DL491e.pdf (accessed on 3 November 2020).

101. FAO (Food and Agriculture Organization of the United Nations). Desert Locust Bulletin, 3 October 2019; No. 492; FAO: Rome, Italy, 2019. Available online: http://www.fao.org/ag/locusts/common/ecg/2484/en/DL492e.pdf (accessed on 3 November 2020).

102. FAO (Food and Agriculture Organization of the United Nations). Desert Locust Bulletin, 4 November 2019; No. 493; FAO: Rome, Italy, 2019. Available online: http:/ / www.fao.org/ag/locusts/common/ecg/2488/en/DL493e.pdf (accessed on 3 November 2020).

103. FAO (Food and Agriculture Organization of the United Nations). Desert Locust Bulletin, 4 December 2019; No. 494; FAO: Rome, Italy, 2019. Available online: http:/ /www.fao.org/ag/locusts/common/ecg/2491/en/DL494e.pdf (accessed on 3 November 2020).

104. FAO (Food and Agriculture Organization of the United Nations). Desert Locust Bulletin, 6 January 2020; No. 495; FAO: Rome, Italy, 2020. Available online: http:/ /www.fao.org/ag/locusts/common/ecg/2514/en/DL495e.pdf (accessed on 3 November 2020).

105. FAO (Food and Agriculture Organization of the United Nations). Desert Locust Bulletin, 3 February 2020; No. 496; FAO: Rome, Italy, 2020. Available online: http:/ /www.fao.org/ag/locusts/common/ecg/2526/en/DL496e.pdf (accessed on 3 November 2020).

106. FAO (Food and Agriculture Organization of the United Nations). Desert Locust Bulletin, 5 March 2020; No. 497; FAO: Rome, Italy, 2020. Available online: http:/ /www.fao.org/ag/locusts/common/ecg/2531/en/DL497e.pdf (accessed on 3 November 2020).

107. FAO (Food and Agriculture Organization of the United Nations). Desert Locust Bulletin, 4 April 2020; No. 498; FAO: Rome, Italy, 2020. Available online: http:/ /www.fao.org/ag/locusts/common/ecg/2536/en/DL498e.pdf (accessed on 3 November 2020).

108. FAO (Food and Agriculture Organization of the United Nations). Desert Locust Bulletin, 3 December 2018; No. 482; FAO: Rome, Italy, 2018. Available online: http:/ / www.fao.org/ag/locusts/common/ecg/2448/en/DL482e.pdf (accessed on 3 November 2020).

109. Meynard, C.N.; Lecoq, M.; Chapuis, M.P.; Piou, C. On the relative role of climate change and management in the current Desert Locust outbreak in East Africa. Glob Chang. Biol. 2020, 26, 3753-3755. [CrossRef] 